\title{
Transcriptional Regulation of Cardiac Development: Implications for Congenital Heart Disease and DiGeorge Syndrome
}

\author{
JONATHAN A. EPSTEIN AND CLAYTON A. BUCK \\ Cardiovascular Division, Department of Medicine, University of Pennsylvania Health System and \\ The Wistar Institute, Philadelphia, PA 19104, U.S.A.
}

\begin{abstract}
In recent years, impressive advances have occurred in our understanding of transcriptional regulation of cardiac development. These insights have begun to elucidate the mystery of congenital heart disease at the molecular level. In addition, the molecular pathways emerging from the study of cardiac development are being applied to the understanding of adult cardiac disease. Preliminary results support the contention that a thorough understanding of molecular programs governing cardiac morphogenesis will provide important insights into the pathogenesis of human cardiac diseases. This review will focus on examples of transcription factors that play critical roles at various phases of cardiac development and their relevance to cardiac disease. This is an exciting and burgeoning area of investigation.
\end{abstract}

ABSTRACT

It is not possible to be all-inclusive, and the reader will note important efforts in the areas of cardiomyocyte determination, left-right asymmetry, cardiac muscular dystrophies, electrophysiology and vascular disease are not covered. For a more complete discussion, the reader is referred to recent reviews including the excellent compilation of observations assembled by Harvey and Rosenthal (1). (Pediatr Res 48: 717-724, 2000)

DGS, DiGeorge syndrome

\section{Abbreviations}

SRF, serum response factor

TGF, transforming growth factor

ECM, extracellular matrix
Cardiac morphogenesis. Most forms of congenital heart disease result from aberrations in cardiac morphogenesis including errors in cardiac septation, valve formation and proper patterning of the great vessels. These defects can be related to specific stages of cardiac development and to specific molecular pathways (known and unknown) functional at each stage (for review, see $(2,3)$ ). A schematic representation of early heart development is depicted in Figure 1. Early in gestation (day 18 in humans or day 7.5 in mouse), cardiac primordia can be identified as bilaterally symmetric components derived from the lateral plate mesoderm. By day 22 (day 8.5 in the mouse) these primordia migrate medially and fuse to form a single heart tube composed of two cell layers (myocardium and endocardium) separated by a vast extracellular matrix, the cardiac jelly. The midline heart tube folds upon itself (cardiac looping) and distinct regions corresponding to future chambers are discernible. By day 25 in humans (day 10.5 in mouse),

Received July 25, 2000; accepted August 9, 2000.

Jonathan A. Epstein, 954 BRB II, 421 Curie Boulevard, Philadelphia, PA 19104, U.S.A.

This work was supported by grants from the NIH (HL62974, HL61475, DK57050), the AHA, and the WW Smith Foundation. localized swellings of the extracellular matrix are invaded by underlying endothelial cells to initiate the formation of the endocardial cushions that will later condense to form the mature cardiac valves. Thereafter, a series of complex septation events results in delineation of the cardiac chambers. By day 34 (day 11.5 in the mouse), neural crest cells have migrated from the dorsal neural tube along aortic arches 3, 4, and 6 and have invaded the outflow tract of the heart. These cells are required to induce septation of the single great vessel emerging from the embryonic heart (the truncus arteriosus), thus forming the aorta and pulmonary artery (4). They contribute to the mesenchymal elements of the ductus arteriosus and great vessels and initiate remodeling of the aortic arches. Cardiac neural crest differentiates into a subpopulation of arterial smooth muscle cells. At birth, the ductus arteriosus closes, thus completing the formation of separate pulmonary and systemic circulations.

Fusion of cardiac primordia. Specific transcriptional regulators have emerged as critical factors for many of these developmental events (see Fig. 1). For example, the GATA4 transcription factor appears to be required for midline fusion of 


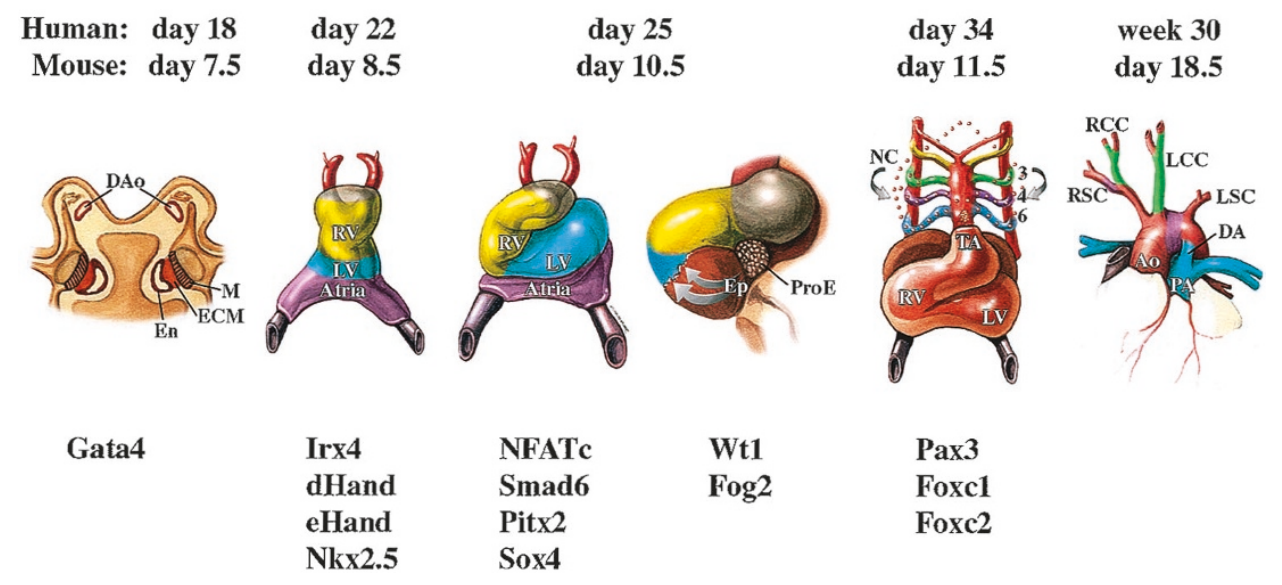

Figure 1. Schematic representation of cardiac development. Approximate human and murine gestational ages are indicated above the drawings and transcription factors discussed in the text are listed below. A schematic cross section through an early embryo is shown in the first panel to indicate the bilaterally symmetric cardiac structures composed of an endocardial tube (En) separated by an extracellular matrix (ECM) from the myocardial precursors (M). Bilateral dorsal aortae (DAo) are indicated. The second panel shows a frontal view of the midline cardiac tube. Gene expression analysis reveals early specification of chambers including right ventricle (RV) and left ventricle (LV). Panels 3 and 4 represent frontal and left lateral views, respectively, of a looped heart tube. The pro-epicardial organ (ProE) is located posteriorly and gives rise to epicardial cells (Ep, shown in brown) that migrate over the ventricles, as indicated by arrows. Panels 5 and 6 depict vascular remodeling. The aortic arches in panel 5 (numbered) are populated by neural crest cells (NC, arrows) and are color coded to match the mature arterial segments indicated in panel 6. TA, truncus arteriosus. RSC, right subclavian artery. RCC, right carotid artery. LCC, left carotid artery. LSC, left subclavian artery. DA, ductus arteriosus. Ao, aorta. PA, pulmonary artery. (Modified from $(1,111)$ ).

the primitive bilateral heart tubes $(5,6)$. GATA transcription factors are defined by the presence of a zinc finger DNA binding domain that recognizes a "GATA" DNA sequence motif. GATA1, 2, and 3 are important during hematopoietic development $(7,8)$, while GATA4, 5, and 6 are expressed in the heart $(9,10)$. Inactivation of GATA4 in the mouse results in early embryonic lethality. Cardiac progenitors are specified, and bilateral primordia can be identified, but a midline cardiac tube fails to form $(5,6)$. GATA factors may have later functions during cardiac development, and may be redundant with one another. Potential GATA binding sites have been found in many cardiac specific gene promoters, and GATA4 is capable of synergizing with other transcription factors such as Nkx2.5 and serum response factor (SRF) to activate cardiac-specific gene expression $(11,12)$. GATA4 may have critical noncardiac functions as well. GATA4 may be required in noncardiac cells (including endoderm) for midline fusion of cardiac primordia since chimeric rescue experiments in the mouse (in which the embryonic endoderm is derived from wild-type cells) rescues midline fusion even though the cardiac cells themselves are GATA4 deficient (13).

Elucidation of molecular pathways regulated by GATA4 in cardiomyocytes has led to important observations that may relate to our understanding and treatment of cardiac hypertrophy and heart failure (14). GATA-associated factors (such as Friend-of-GATA (FOG) or FOG2) may be involved in Tetralogy of Fallot, coronary vascular anomalies or other congenital defects. Both FOG2 and nuclear factor of activated T cells 3 (NFAT3) have been identified as potential heterodimerization partners for GATA4 (14). Since NFAT3 is activated by calcineurin in response to changes in intracellular calcium, it is possible that an NFAT3-GATA4 transcriptional complex mediates some aspects of the hypertrophic response triggered by rising intracellular calcium. Perhaps this pathway results in the well described re-initiation of the "fetal gene program" char- acteristic of cardiac hypertrophy and subsequent heart failure, though this model remains controversial (15-21).

Chamber specification. A growing number of transcription factors are expressed in chamber-specific patterns, and are likely to be responsible for specifying chamber identity. Cardiac chambers are morphologically distinct even at early stages of development (Fig. 1) $(2,3)$. It is becoming evident that these differences are unlikely to be explained by differences in hemodynamics. Rather, programmed differences in gene expression appear to determine cell fate and regional identity. This paradigm is reminiscent of neuronal cell fate determination mediated by the overlapping pattern of Hox gene expression (the "Hox code") along the anteroposterior neural axis of the embryo (for review, see (22)). Recently, a novel Iroquoisrelated homeobox gene, $\operatorname{Ir} x 4$, has been described that exhibits ventricular-specific expression during development (23). Tissue-specific gene inactivation and transgenic over-expression experiments will be important to determine if $\operatorname{Ir} x 4$ is involved in ventricular specification.

The basic helix-loop-helix transcription factors dHand and eHand are expressed predominantly in right and left ventricles during mouse development (24). In chick embryos, their chamber-specific expression pattern is less distinct. $d$ Hand deficient embryos form a poorly developed right ventricle, though the tissue appears to be correctly specified (25). Hypoplastic right and left ventricle syndromes may be related to mutations in these or similar factors (26). In addition, dHand is expressed in regions populated by neural crest cells, and analysis of potential downstream genes regulated by dHand has provided candidate genes for DiGeorge syndrome.

Looping morphogenesis. Inactivation of the $N k \times 2.5$ homeobox gene in the mouse results in failure of looping morphogenesis $(27,28)$. This gene encodes a DNA binding protein containing a 60 amino acid helix-turn-helix motif related to homeobox-containing $(H O X)$ genes that regulate early embry- 
onic patterning. It is closely related to the tinman gene of the fruit fly Drosophila melanogaster (29). In the fly, tinman is required for formation of the dorsal vessel, a structure that appears to represent the evolutionary ancestor of the mammalian heart. Many related $N k x$ genes are expressed in mammals in overlapping patterns (30), but $N k \times 2.5$ appears to play a unique function in cardiac development. It is expressed from the earliest stages of cardiomyocyte determination. Although mutant embryos are able to form a primitive heart tube and express cardiac specific genes including myosin, they die during mid-gestation and the heart fails to loop normally (28). The transcriptional regulation of $N k x 2.5$ expression is complex. A series of elegant reports, reviewed elsewhere (31), indicate that chamber-specific expression is regulated by distinct enhancer sequences. This suggests that chamber-specific upstream factors that mediate $N k x 2.5$ expression exist in a regionspecific fashion. These factors are also likely to participate in defining chamber-specific identity (e.g., atrial versus ventricular, right ventricular versus left ventricular). Recently, hypomorphic alleles and heterozygous loss-of-function of $N k \times 2.5$ have been shown to result in atrial septation defects and conduction abnormalities in humans $(32,33)$.

Valvulogenesis. Endocardial cushion defects and congenital valvular abnormalities, including pulmonic and aortic stenosis, bicuspid aortic valve, mitral valve prolapse and cleft mitral valve, are common. Abnormalities of recently described molecular pathways are likely to account for at least some of these cases. Transcriptional regulators such as NFATc, the Sryrelated homeobox gene Sox4, and the downstream modulator of TGF $\beta$ superfamily signaling Smad6 are required for proper endocardial cushion formation and maturation (34-37). Members of the TGF $\beta$ family of secreted growth factors, the type III TGF $\beta$ receptor, and the EGF receptor are also involved (3840). These receptors may mediate intracellular signals through the small GTP binding protein ras, since mutation in the ras-GAP protein encoded by the Neurofibromatosis gene $N F 1$ disrupt valvulogenesis (41-43). Interestingly, there appears to be an increased incidence of valvular pulmonic stenosis in patients with von Recklinghausen Neurofibromatosis associated with mutations in the NF1 gene (44-46). It will be of interest to determine whether somatic mutations in the NFI gene account for some sporadic cases of pulmonic stenosis.

Inactivation of the murine bicoid type homeobox gene Pitx2 also results in enlargement of the endocardial cushions, though Pitx2 itself is expressed in the myocardium overlying the cushion region (47-49). Pitx2 plays an important role in left-right patterning and homozygous deficient mice also display a hypoplastic right ventricle and atrio-ventricular septal defects. Heterozygous mutations in the human homologue of Pitx2, RIEG, cause Rieger syndrome characterized by tooth and eye developmental defects (50). Cardiac and laterality defects are not commonly associated with Reiger syndrome.

Epicardial-derived cells contribute to the forming endocardial cushions and coronary vessels. The epicardium is derived from cells emerging from the pro-epicardial organ which is located posterior to the forming heart (Fig. 1, panel 4). Cells migrate from this embryonic structure and envelop the myocardium in a caudal-to-rostral direction. Some epicardial cells invade the myocardium and populate the endocardial cushions. Others contribute to the formation of intramyocardial capillaries (51). Signals mediated by retinoic acid (RA) are probably critical for this process as suggested by the expression of a critical enzyme in RA biosynthesis, retinaldehyde dehydrogenase type II (RALDH2) (52). The product of the Wilms' tumor gene $W T 1$, a nuclear transcription factor, is also required for epicardial development (53) as is FOG2 (54). An exciting area of active research relates to the role of epicardial cells in myocardial maturation, coronary artery development and valvulogenesis. This process, as well as cardiac neural crest function, may be altered by mutations in retinoic acid receptors in mice $(55,56)$, and by teratogens such as retinoic acid or by vitamin A deficiency in humans.

Outflow tract septation and patterning of the great vessels. Neural crest cells populate many regions of the developing embryo and differentiate into numerous cell types, forming the peripheral nervous system, melanocytes, and contributing to the thyroid, parathyroid and thymus glands. Classic studies performed in developing chick embryos demonstrated that neural crest cells migrate from the neural tube, along the aortic arches, and populate the outflow tract and outflow endocardial cushions during mid-gestation (4). Ablation of a discreet subset of cranial neural crest cells before emergence from the neural tube results in predictable cardiac malformations including persistent truncus arteriosus, double outlet right ventricle, interrupted aortic arch and related defects (4). In mice, mutations in the paired-box-containing gene $\operatorname{Pax} 3$ result in similar defects (57). In both ablated chicks and Pax3-deficient (Splotch) mice, defects in thymus, thyroid and parathyroid derivatives are also apparent. This phenotype in Splotch mice is strikingly reminiscent of human patients with DiGeorge syndrome (see below). While mutations in $P A X 3$ have not been shown to cause DiGeorge syndrome in man, it is likely that similar molecular and developmental pathways are affected, making Splotch mice a potentially useful model for the study of neural crest related cardiac defects. Using a neural crest-specific element in the Pax3 promoter to direct expression of Cre recombinase in transgenic mice, cardiac neural crest cells have been fatemapped to the aorto-pulmonary septum, aortic arches, ductus arteriosus and outflow endocardial cushions (Fig. 2 (58), and JAE, unpublished results). Later in development, they differentiate into smooth muscle cells in the aortic arch and head vessels. These regions of the forming vasculature seem particularly sensitive to genetic perturbations. They are affected by several signaling cascades including those mediated by the endothelin receptor A (59), endothelin 1 (60), endothelin converting enzyme $1(61)$ and by the winged helix transcription factors Foxc1 (Mf1) and Foxc2 (Mfh1) (62). Mutations in these genes in mice lead to interruptions of the aorta. Interestingly, mutation of the secreted semaphorin signaling molecule Sema3C also leads to interrupted aortic arch (L. Feiner, JAE and J. Raper, personal communication). Semaphorins act in the CNS to mediate axon pathfinding by causing growth cone collapse, and may similarly function during cardiac development to direct neural crest migration. A potential Sema3C receptor, PlexinA2, is expressed by cardiac neural crest cells (JAE, unpublished results). Future studies will be needed to 

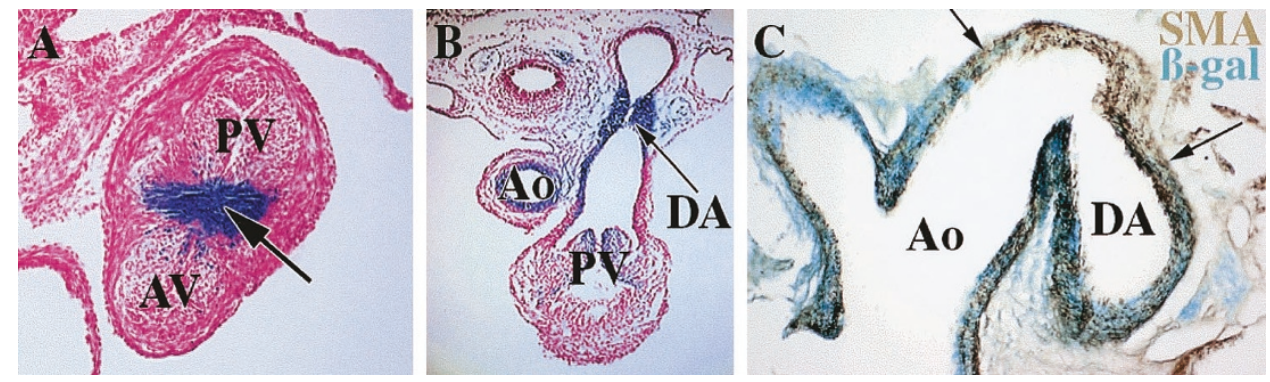

Figure 2. Fate-mapping of cardiac neural crest cells. Mouse embryos carrying Cre recombinase under the control of the neural crest-specific element of the Pax3 promoter were crossed with transgenic mice carrying a Cre-reporter that expresses $\beta$-galactosidase ( $\beta$-gal) in response to Cre activity. Once Cre recombinase is activated by the Pax 3 promoter, $\beta$-gal is expressed. It will continue to be expressed constitutively by that cell and by all daughter cells. Hence, the fate of the Pax3 expressing neural crest precursors can be followed during cardiovascular development. (A) At embryonic day 12.5 neural crest cells (arrow) contribute to the forming aorto-pulmonary septum at the level of the aortic valve (AV) and pulmonic valve (PV). (B) At embryonic day 18.5, neural crest descendants contribute to the wall of the aorta (Ao), to the tips of the pulmonic valve and to the cushions of the ductus arteriosus (DA). (C) Immunohistochemistry using a smooth muscle actin (SMA) specific antibody demonstrates that $\beta$-gal positive neural crest descendants become smooth muscle cells in the aortic arch. $\beta$-gal positive cells do not contribute to the smooth muscle of the descending aorta beyond the ductus arteriosus. This transition point is indicated by arrows in C.

determine whether mutations in any of these genes account for interruptions or coarctations of the aorta in humans.

DiGeorge Syndrome. DiGeorge Syndrome (DGS), also known as velocardiofacial syndrome (VCFS), has received a good deal of attention in the past few years (for reviews see (63-68)). It is one of the most common congenital defects occurring with a frequency of $1 / 4000$ live births. It is characterized by a constellation of abnormalities suggestive of defective cranial neural crest function particularly with respect to neural crest populating aortic arches 3 and 4. These include cardiac outflow tract anomalies, abnormal facies, thymic hypoplasia, cleft palate, hypocalcemia and a microdeletion on chromosome 22, hence the acronym $\mathrm{CATCH} 22$. The microdeletion can result in haploid insufficiency of up to 30 genes $(69$, 70).

Understanding the etiology of DGS has been confounded by several observations including the fact that the severity of the phenotype is not related to the size of the deletion. DGS patients can carry deletions of up to 3 megabases. However, there are patients with considerably smaller deletions with equally severe phenotypes. In fact, a balanced translocation between chromosome 2 and 22, ADU (t2;22) that did not involve a loss of DNA resulted in a mild DGS phenotype (71). Theoretically, this translocation should have resulted in the disruption of a single gene. This was not the case. The break point did not appear to affect any specific gene directly (7274). These observations have led investigators to propose the existence of "functional architecture" within this region of chromosome 22, the disruption of which leads to aberrant regulation of a gene or genes required for cranial neural crest function. The complexity of the situation is further documented by reports showing DGS-like phenotypes resulting from haploid deletions involving chromosome $10 \mathrm{p}(75,76)$. Clearly, the genetic control of outflow tract assembly is such that perturbations of the function of any one or combination of several genes can result in phenotypes associated with DGS (see previous discussion).

Several hypotheses have been put forth to explain the etiology of DGS. The simplest is that there is a "DiGeorge gene" within the deleted region of 22q11.2 whose function is dosage dependent. That is, loss or mutation of one copy of the gene changes the amount of product available adversely affecting a crucial step in cranial neural crest function. This has led to the search for patients with mutations in candidate genes. An interesting candidate gene was proposed by Yamagishi et al. (77). They identified $U f d 1 L$ as a probable downstream target of $d$ Hand, a gene required for early heart development (see above). UfdlL is the mouse homolog of the yeast ubiquitin fusion degradation protein 1 gene. It encodes a protein possibly required for targeting proteins for degradation. Thus, a deficiency in this protein might lead to the accumulation of unwanted proteins resulting in cell death (apoptosis) or aberrant differentiation. A screen of 182 DGS patients revealed UFDIL was included in all deletions. Most interesting, one patient was discovered with a deletion of UFDIL, and while a portion of the gene $C D C 45 L$ immediately proximal to $U F D I L$ was also missing, UFDIL appeared the more likely causal target (77). In an attempt to confirm this observation, many groups have screened patients for single mutations in UFD1L (for example see (78)). To date, none have been found. Further, mice carrying a heterozygous deletion in this gene showed no evidence of a DGS phenotype despite a $50 \%$ reduction in message (79).

Another interesting candidate gene is HIRA, which encodes a transcription factor that interacts with Pax3 (80). Treatment of chick embryos with antisense ribonucleotides targeting chHira mRNA results in outflow tract abnormalities, particularly persistent truncus arteriosus, that resemble those accompanying DGS (81). However, no patients with point mutations in HIRA have been reported. A variety of other candidate genes are found within the 22q11.2 deletion (see Table 1). These include genes encoding putative transcription factors, extracellular matrix molecules, cell surface receptors, transport proteins, and protein kinases. Again, no single mutations leading to DGS have been identified. Further, where tested, mice heterozygous for mutations in genes homologous to those found within the DiGeorge region display no abnormal phe- 
Table 1. Genes within the region of chromosome $22 q 11$ commonly deleted in DiGeorge syndrome listed in order from centromere to telomere (see Fig. 3)

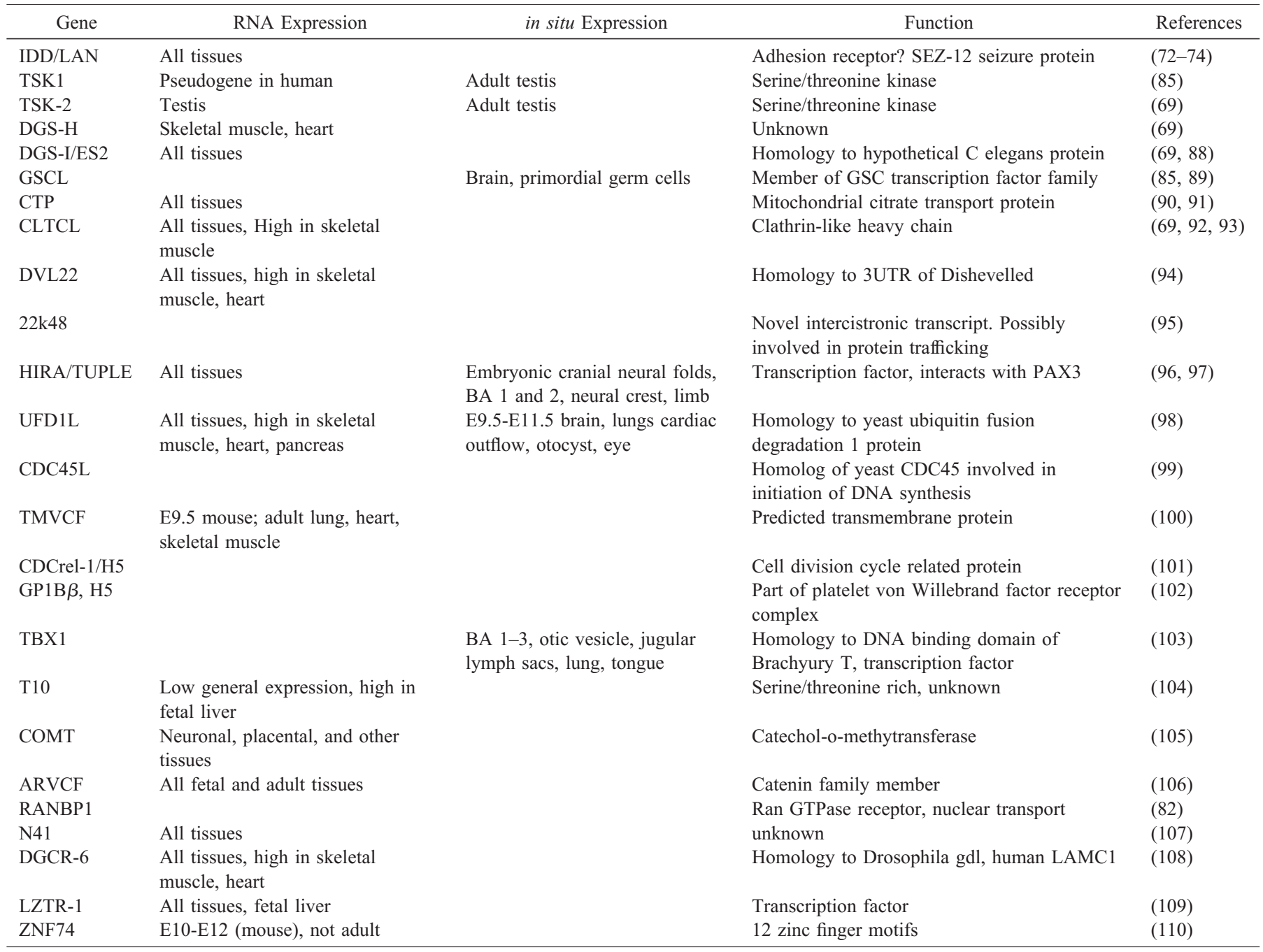

RNA expression by Northern blot analysis is summarized (column 2) in addition to RNA and/or protein expression as detected by in situ hybridization or immunohistochemistry (column 3). Known or presumed functional data is listed in column 4 . BA = branchial arches.

notypes. Thus, to date, there is no strong evidence for the existence of a single "DiGeorge gene."

Another approach to understanding the etiology of DGS has been to create an animal model carrying deletions that involve clusters of genes similar to those deleted in DiGeorge patients. This approach depends upon the conservation of synteny between human and mouse chromosomes. The "DiGeorge region" of human 22q11 is conserved within mouse chromosome 16. The relative order of most genes within the syntenic region is conserved with certain blocks of genes being inverted in the mouse with respect to the centromere-telemere orientation (Fig. 3) (82-85). The function of genes within this complex has been tested in mice by deleting entire segments of chromosome 16 corresponding to those noted in DGS patients. In one case, mice carrying deletions of a region within the "minimal DiGeorge critical region" (MDGCR) were constructed (86). The MDGCR represents the smallest portion of the 22q11.2 deletion common to most DiGeorge patients. While animals homozygous for the $150-\mathrm{Kb}$ deletion died early in gestation, heterozygous animals were without significant morphogenetic phenotypes. This is consistent with the recent identification of DGS patients with deletions completely outside the MDGCR (87).

In another study, animals carrying a larger 1.2 megabase deletion were constructed (Fig. 3). In this case, heterozygous deleted animals survived and displayed heart anomalies resulting from abnormal remodeling of the fourth brachial arch arteries reminiscent of vascular anomalies accompanying DGS (79). The phenotype was reversed by duplication of the deleted region proving that it was caused by haploid insufficiency of one or more genes within this deleted region and not by a position effect. Interestingly, in the genetic backgrounds reported, the defects were specific for aortic arch IV derivatives and did not include many OFT defects, facial dysmorphias, cleft palate, thyroid or parathyroid hypoplasias characteristic of DGS. Thus, while this deleted region includes genes required for certain aspects of aortic arch development, there must be additional genes residing outside this region that act as modifiers and are important to other aspects of early heart and facial morphogenesis relevant to the DGS. This presumption is sup- 


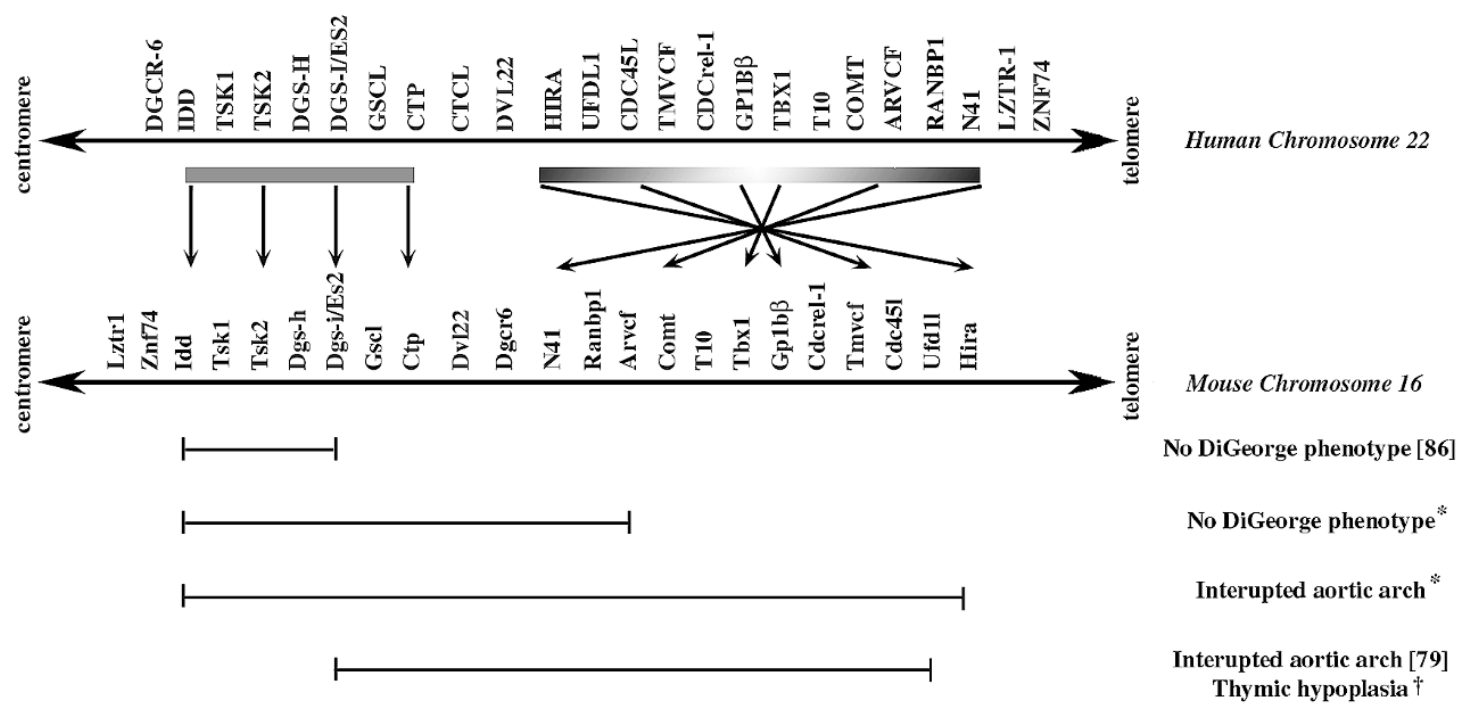

Figure 3. The DiGeorge region of human chromosome 22. The region of chromosome $22 \mathrm{q} 11$ commonly deleted in DiGeorge syndrome is shown schematically with the syntenic region of mouse chromosome 16 (modified from (79)). Genes within this region are indicated (spacing is not to scale). The expression pattern and function of these genes are summarized in Table 1. A segment of this genomic locus is inverted in the mouse compared with the human as indicated by the crossed arrows. Genomic deletions in the mouse have been engineered to produce mouse models of DiGeorge syndrome. The extent of each of four deletions is indicated below the mouse chromosome with the resulting phenotype indicated at the right. Taken together, these results suggest that a relatively small region between Arvcf and UfdIL contains at least one gene required for aortic arch remodeling and neural crest development. (*A. Skoultchi and R. Kucherlapati, personal communication; †A. Baldini, personal communication).

ported by preliminary evidence that thymus hypoplasia becomes apparent when these mice are crossed onto different genetic backgrounds (A. Baldini, personal communication). Additional engineered deletions, in progress in several labs around the world, will continue to refine the region of mouse chromosome 16 containing genes critical for cardiovascular development and neural crest function (see Fig. 3). For instance, a group at Albert Einstein University has created a deletion that removes the genes between Idd and Arvcf that does not produce any DiGeorge-like characteristics in the heterozygous state. However, a larger deletion extending from Idd to Hira does produce interrupted aortic arch (A. Skoultchi, R. Kucherlapati, personal communication). Systematic complementation of genes across the deletion should lead to the identification of those critical to the DGS phenotype. Thus, while the origin of DGS remains a mystery, critical and informative experiments are underway. The ability to construct elegant animal models, the completion of the human genome project and our emerging understanding of chromosomal structure and gene regulation, suggest that we should soon begin to understand the molecular origin of dysmorphias characteristic of DGS.

In summary, transcription factors that play critical functions at specific stages of cardiac development are emerging from basic studies, providing excellent candidate genes responsible for various forms of congenital and adult cardiac diseases. While complete loss-of-function in animal models often results in severe cardiac morphogenetic defects, more subtle mutations are being found in humans with milder forms of structural heart disease. Molecular pathways deciphered from the study of developmental processes may be reiterated during pathologic adult cardiac conditions. The further study of molecular determinants of embryonic cardiac development offers a rational approach for the identification of disease causing genes.

Acknowledgment. Drawings shown in Figure 1 were created by Paul Schiffmacher.

\section{REFERENCES}

1. Harvey RP, Rosenthal N 1999 Heart Development. Academic Press, San Diego, pp $1-488$

2. Fishman MC, Chien KR 1997 Fashioning the vertebrate heart: earliest embryonic decisions. Development 124:2099-2117

3. Olson EN, Srivastava D 1996 Molecular pathways controlling heart development. Science 272:671-676

4. Kirby ML, Gale TF, Stewart DE 1983 Neural crest cells contribute to normal aorticopulmonary septation. Science 220:1059-1061

5. Kuo CT, Morrisey EE, Anandappa R, Sigrist K, Lu MM, Parmacek MS, Soudais C, Leiden JM 1997 GATA4 transcription factor is required for ventral morphogenesis and heart tube formation. Gene Dev 11:1048-1060

6. Molkentin JD, Lin Q, Duncan SA, Olson EN 1997 Requirement of the transcription factor GATA4 for heart tube formation and ventral morphogenesis. Gene Dev 11:1061-1072

7. Orkin SH 1992 GATA-binding transcription factors in hematopoietic cells. Blood 80:575-581

8. Weiss MJ, Orkin SH 1995 GATA transcription factors: key regulators of hematopoiesis. Exp Hematol 23:99-107

9. Laverriere AC, MacNeill C, Mueller C, Poelmann RE, Burch JB, Evans T 1994 GATA-4/5/6, a subfamily of three transcription factors transcribed in developing heart and gut. J Biol Chem 269:23177-23184

10. Charron F, Nemer M 1999 GATA transcription factors and cardiac development. Semin Cell Dev Biol 10:85-91

11. Durocher D, Charron F, Warren R, Schwartz RJ, Nemer M 1997 The cardiac transcription factors Nkx2-5 and GATA-4 are mutual cofactors. Embo J 16:56875696

12. Sepulveda JL, Belaguli N, Nigam V, Chen CY, Nemer M, Schwartz RJ 1998 GATA-4 and Nkx-2.5 coactivate Nkx-2 DNA binding targets: role for regulating early cardiac gene expression. Mol Cell Biol 18:3405-3415

13. Narita N, Bielinska M, Wilson DB 1997 Wild-type endoderm abrogates the ventral developmental defects associated with GATA-4 deficiency in the mouse. Dev Biol 189:270-274

14. Molkentin JD, Lu JR, Antos CL, Markham B, Richardson J, Robbins J, Grant SR, Olson EN 1998 A calcineurin-dependent transcriptional pathway for cardiac hypertrophy. Cell 93:215-228 
15. Olson EN, Molkentin JD 1999 Prevention of cardiac hypertrophy by calcineurin inhibition: hope or hype? Circ Res 84:623-632

16. Sussman MA, Lim HW, Gude N, Taigen T, Olson EN, Robbins J, Colbert MC Gualberto A, Wieczorek DF, Molkentin JD 1998 Prevention of cardiac hypertrophy in mice by calcineurin inhibition. Science 281:1690-1693

17. Tsao L, Neville C, Musaro A, McCullagh KJ, Rosenthal N 2000 Revisiting calcineurin and human heart failure. Nat Med 6:2-3

18. Lim HW, Molkentin JD 1999 Calcineurin and human heart failure. Nat Med $5: 246-247$

19. Ding B, Price RL, Borg TK, Weinberg EO, Halloran PF, Lorell BH 1999 Pressure overload induces severe hypertrophy in mice treated with cyclosporine, an inhibitor of calcineurin. Circ Res 84:729-734

20. Zhang W, Kowal RC, Rusnak F, Sikkink RA, Olson EN, Victor RG 1999 Failure of calcineurin inhibitors to prevent pressure-overload left ventricular hypertrophy in rats. Circ Res 84:722-728

21. Lim HW, Molkentin JD 2000 Reply to revisiting calcineurin and human hear failure. Nat Med 6:3

22. Krumlauf R, Marshall H, Studer M, Nonchev S, Sham MH, Lumsden A 1993 Hox homeobox genes and regionalisation of the nervous system. J Neurobiol 24:1328 1340

23. Bao ZZ, Bruneau BG, Seidman JG, Seidman CE, Cepko CL 1999 Regulation of chamber-specific gene expression in the developing heart by Irx4. Science 283:1161-1164

24. Srivastava D, Cserjesi P, Olson EN 1995 A subclass of bHLH proteins required for cardiac morphogenesis. Science 270:1995-1999

25. Srivastava D, Thomas T, Lin Q, Kirby ML, Brown D, Olson EN 1997 Regulation of cardiac mesodermal and neural crest development by the bHLH transcription factor, dHAND. Nat Genet 16:154-160

26. Thomas T, Yamagishi H, Overbeek PA, Olson EN, Srivastava D 1998 The bHLH factors, dHAND and eHAND, specify pulmonary and systemic cardiac ventricles independent of left-right sidedness. Dev Biol 196:228-236

27. Komuro I, Izumo S 1993 Csx: a murine homeobox-containing gene specifically expressed in the developing heart. Proc Natl Acad Sci USA 90:8145-8149

28. Lyons I, Parsons LM, Hartley L, Li R, Andrews JE, Robb L, Harvey RP 1995 Myogenic and morphogenetic defects in the heart tubes of murine embryos lacking the homeo box gene Nkx2-5. Gene Dev 9:1654-1666

29. Bodmer R 1993 The gene tinman is required for specification of the heart and visceral muscles in Drosophila. Development 118:719-729

30. Harvey RP 1996 NK-2 homeobox genes and heart development. Dev Biol 178:203216

31. Schwartz RJ, Olson EN 1999 Building the heart piece by piece: modularity of cis-elements regulating Nkx2-5 transcription. Development 126:4187-4192

32. Schott JJ, Benson DW, Basson CT, Pease W, Silberbach GM, Moak JP, Maron BJ, Seidman CE, Seidman JG 1998 Congenital heart disease caused by mutations in the transcription factor NKX2-5. Science 281:108-111

33. Benson DW, Silberbach GM, Kavanaugh-McHugh A, Cottrill C, Zhang Y, Riggs S Smalls O, Johnson MC, Watson MS, Seidman JG, Seidman CE, Plowden J, Kugler JD 1999 Mutations in the cardiac transcription factor NKX2.5 affect diverse cardiac developmental pathways. J Clin Invest 104:1567-1573

34. Ranger AM, Grusby MJ, Hodge MR, Gravallese EM, de la Brousse FC, Hoey T, Mickanin C, Baldwin HS, Glimcher LH 1998 The transcription factor NF-ATc is essential for cardiac valve formation. Nature 392:186-190

35. de la Pompa JL, Timmerman LA, Takimoto H, Yoshida H, Elia AJ, Samper E, Potte J, Wakeham A, Marengere L, Langille BL, Crabtree GR, Mak TW 1998 Role of the NF-ATc transcription factor in morphogenesis of cardiac valves and septum. Nature 392:182-186

36. Schilham MW, Oosterwegel MA, Moerer P, Ya J, de Boer PA, van de Wetering M, Verbeek S, Lamers WH, Kruisbeek AM, Cumano A, Clevers H 1996 Defects in cardiac outflow tract formation and pro-B-lymphocyte expansion in mice lacking Sox-4. Nature 380:711-714

37. Galvin KM, Donovan MJ, Lynch CA, Meyer RI, Paul RJ, Lorenz JN, FairchildHuntress V, Dixon KL, Dunmore JH, Gimbrone MA, Jr., Falb D, Huszar D 2000 A role for smad6 in development and homeostasis of the cardiovascular system. Nat Genet 24:171-174

38. Potts JD, Runyan RB 1989 Epithelial-mesenchymal cell transformation in the embryonic heart can be mediated, in part, by transforming growth factor beta. Dev Biol 134:392-401

39. Brown CB, Boyer AS, Runyan RB, Barnett JV 1999 Requirement of type III TGF-beta receptor for endocardial cell transformation in the heart. Science 283:2080-2082

40. Chen B, Bronson RT, Klaman LD, Hampton TG, Wang JF, Green PJ, Magnuson T, Douglas PS, Morgan JP, Neel BG 2000 Mice mutant for Egfr and Shp2 have defective cardiac semilunar valvulogenesis. Nat Genet 24:296-299

41. Jacks T, Shih TS, Schmitt EM, Bronson RT, Bernards A, Weinberg RA 1994 Tumour predisposition in mice heterozygous for a targeted mutation in Nf1. Nat Genet 7:353-361

42. Brannan CI, Perkins AS, Vogel KS, Ratner N, Nordlund ML, Reid SW, Buchberg AM, Jenkins NA, Parada LF, Copeland NG 1994 Targeted disruption of the neurofibromatosis type-1 gene leads to developmental abnormalities in heart and various neural crest-derived tissues. Genes Dev 8:1019-1029

43. Lakkis MM, Epstein JA 1998 Neurofibromin modulation of ras activity is required for normal endocardial-mesenchymal transformation in the developing heart. Development 125:4359-4367

44. Kaufman RL, Hartmann A, McAlister WH 1972 Family studies in congenital heart disease IV: Congenital heart disease associated with neurofibromatosis. Birth Defects: Original Articles Series VIII 92-95
45. Colley A, Donnai D, Evans DG 1996 Neurofibromatosis/Noonan phenotype: a variable feature of type 1 neurofibromatosis. Clin Genet 49:59-64

46. Lin AE, Birch PH, Korf BR, Schneider GH, Tenconi R, Niimura M, Poyhonen M Armfield HK, Sigorini M, Virdis R, Romano C, Bonioli E, Wolkenstein P, Pivnick EK, Lawrence M, Friedman JM, and the NNFF International Database Participants 2000 Cardiovascular malformations and other cardiac abnormalities in neurofibromatosis 1 (NF1). Am J Med Genet in press

47. Lin CR, Kioussi C, O'Connell S, Briata P, Szeto D, Liu F, Izpisua-Belmonte JC, Rosenfeld MG 1999 Pitx2 regulates lung asymmetry, cardiac positioning and pituitary and tooth morphogenesis. Nature 401:279-282

48. Lu MF, Pressman C, Dyer R, Johnson RL, Martin JF 1999 Function of Rieger syndrome gene in left-right asymmetry and craniofacial development. Nature 401:276-278

49. Ryan AK, Blumberg B, Rodriguez-Esteban C, Yonei-Tamura S, Tamura K, Tsukui T, de la Pena J, Sabbagh W, Greenwald J, Choe S, Norris DP, Robertson EJ, Evan RM, Rosenfeld MG, Izpisua Belmonte JC 1998 Pitx2 determines left-right asymmetry of internal organs in vertebrates. Nature 394:545-551

50. Semina EV, Reiter R, Leysens NJ, Alward WL, Small KW, Datson NA, SiegelBartelt J, Bierke-Nelson D, Bitoun P, Zabel BU, Carey JC, Murray JC 1996 Cloning and characterization of a novel bicoid-related homeobox transcription factor gene, RIEG, involved in Rieger syndrome. Nat Genet 14:392-399

51. Vrancken Peeters MP, 199 Gittenberger-de Groot AC, Mentink MM, Poelmann RE 1999 Smooth muscle cells and fibroblasts of the coronary arteries derive from epithelial-mesenchymal transformation of the epicardium. Anat Embryol (Berl)199:367-378

52. Xavier-Neto J, Shapiro MD, Houghton L, Rosenthal N 2000 Sequential programs of retinoic acid synthesis in the myocardial and epicardial layers of the developing avian heart. Dev Biol 219:129-141

53. Moore AW, McInnes L, Kreidberg J, Hastie ND, Schedl A 1999 YAC complementation shows a requirement for Wt1 in the development of epicardium, adrenal gland and throughout nephrogenesis. Development 126:1845-1857

54. Tevosian SG, Deconinck AE, Tanaka M, Schinke M, Litovsky SH, Izumo S, Fujiwara Y, Orkin SH 2000 FOG-2, a cofactor for GATA transcription factors, is essential for heart morphogenesis and development of coronary vessels from epicardium Cell 101:729-739

55. Gruber PJ, Kubalak SW, Pexieder T, Sucov HM, Evans RM, Chien KR 1996 RXR alpha deficiency confers genetic susceptibility for aortic sac, conotruncal, atrioventricular cushion, and ventricular muscle defects in mice. J Clin Invest 98:1332-1343

56. Mendelsohn C, Lohnes D, Decimo D, Lufkin T, LeMeur M, Chambon P, Mark M 1994 Function of the retinoic acid receptors (RARs) during development (II) Multiple abnormalities at various stages of organogenesis in RAR double mutants. Development 120:2749-2771

57. Epstein JA 1996 Pax3, neural crest and cardiovascular development. Trends Cardiovasc Med 6:255-261

58. Epstein JA, Li J, Lang D, Chen F, Brown CB, Jin F, Lu MM, Thomas M, Liu E, Wessels A, Lo CW 2000 Migration of cardiac neural crest cells in splotch embryos. Development 127:1869-1878

59. Yanagisawa H, Hammer RE, Richardson JA, Williams SC, Clouthier DE, Yanagisawa M 1998 Role of Endothelin-1/Endothelin-A receptor-mediated signaling pathway in the aortic arch patterning in mice. J Clin Invest 102:22-33

60. Kurihara Y, Kurihara H, Oda H, Maemura K, Nagai R, Ishikawa T, Yazaki Y 1995 Aortic arch malformations and ventricular septal defect in mice deficient in endothelin-1. J Clin Invest 96:293-300

61. Yanagisawa H, Yanagisawa M, Kapur RP, Richardson JA, Williams SC, Clouthier DE, de Wit D, Emoto N, Hammer RE 1998 Dual genetic pathways of endothelinmediated intercellular signaling revealed by targeted disruption of endothelin converting enzyme-1 gene. Development 125:825-836

62. Winnier GE, Kume T, Deng K, Rogers R, Bundy J, Raines C, Walter MA, Hogan BL, Conway SJ 1999 Roles for the winged helix transcription factors MF1 and MFH1 in cardiovascular development revealed by nonallelic noncomplementation of null alleles. Dev Biol 213:418-431

63. Burn J 1999 Closing time for CATCH22. J Med Genet 36:737-738

64. Driscoll DA 1994 Genetic basis of DiGeorge and velocardio-facial syndromes. Curr Opin Pediat 6:702-706

65. Glover TW 1995 CATCHing a break on 22. Nat Genet 10:257-258

66. McDonald-McGinn DM, Kirschner R, Goldmuntz E, Sullivan K, Eicher P, Gerdes M, Moss E, Solot C, Wang P, Jacobs I, Handler S, Knightly C, Heher K, Wilson M, Ming JE, Grace K, Driscoll D, Pasquariello P, Randall P, Larossa D, Emanuel BS, Zackai EH 1999 The Philadelphia story: the 22q11.2 deletion: report on 250 patients. Genet Couns 10:11-24

67. Scambler PJ 1999 Genetics. Engineering a broken heart. Nature 401:335-357

68. Wilson DI, Burn J, Scambler P, Goodship J 1993 DiGeorge syndrome: part of CATCH 22. J Med Genet 30:852-856

69. Gong W, Emanuel BS, Collins J, Kim DH, Wang Z, Chen F, Zhang G, Roe B, Budarf ML 1996 A transcription map of the DiGeorge and velocardio-facial syndrome minimal critical region on 22q11. Hum Mol Genet 5:789-800

70. Sutherland HF, Kim UJ, Scambler PJ 1998 Cloning and comparative mapping of the DiGeorge syndrome critical region in the mouse. Genomics 52:37-43

71. Augusseau S, Jouk S, Jalbert P, Prieur M 1986 DiGeorge syndrome and 22q11 rearrangements. Hum Genet 74:206

72. Budarf ML, Collins J, Gong W, Roe B, Wang Z, Bailey LC, Sellinger B, Michaud D, Driscoll DA, Emanuel BS 1995 Cloning a balanced translocation associated with DiGeorge syndrome and identification of a disrupted candidate gene. Nat Genet $10: 269-278$

73. Demczuk S, Aledo R, Zucman J, Delattre O, Desmaze C, Dauphinot L, Jalbert P, Rouleau GA, Thomas G, Aurias A 1995 Cloning of a balanced translocation 
breakpoint in the DiGeorge syndrome critical region and isolation of a novel potential adhesion receptor gene in its vicinity. Hum Mol Genet 4:551-558

74. Wadey R, Daw S, Taylor C, Atif U, Kamath S, Halford S, O'Donnell H, Wilson D, Goodship J, Burn J, et al 1995 Isolation of a gene encoding an integral membrane protein from the vicinity of a balanced translocation breakpoint associated with DiGeorge syndrome. Hum Mol Genet 4:1027-1033

75. Daw SC, Taylor C, Kraman M, Call K, Mao J, Schuffenhauer S, Meitinger T, Lipson T, Goodship J, Scambler P 1996 A common region of 10p deleted in DiGeorge and velocardiofacial syndromes. Nat Genet 13:458-460

76. Gottlieb S, Driscoll DA, Punnett HH, Sellinger B, Emanuel BS, Budarf ML 1998 Characterization of $10 \mathrm{p}$ deletions suggests two nonoverlapping regions contribute to the DiGeorge syndrome phenotype. Am J Hum Genet 62:495-498

77. Yamagishi H, Garg V, Matsuoka R, Thomas T, Srivastava D 1999 A molecular pathway revealing a genetic basis for human cardiac and craniofacial defects Science 283:1158-1161

78. Wadey R, McKie J, Papapetrou C, Sutherland H, Lohman F, Osinga J, Frohn I, Hofstra R, Meijers C, Amati F, Conti E, Pizzuti A, Dallapiccola B, Novelli G, Scambler P 1999 Mutations of UFD1L are not responsible for the majority of cases of DiGeorge Syndrome/velocardiofacial syndrome without deletions within chromosome 22q11. Am J Hum Genet 65:247-249

79. Lindsay EA, Botta A, Jurecic V, Carattini-Rivera S, Cheah YC, Rosenblatt HM, Bradley A, Baldini A 1999 Congenital heart disease in mice deficient for the DiGeorge syndrome region. Nature 401:379-383

80. Magnaghi P, Roberts C, Lorain S, Lipinski M, Scambler PJ 1998 HIRA, a mammalian homologue of Saccharomyces cerevisiae transcriptional co-repressors, interacts with Pax3. Nat Genet 20:74-77

81. Farrell MJ, Stadt H, Wallis KT, Scambler P, Hixon RL, Wolfe R, Leatherbury L, Kirby ML 1999 HIRA, a DiGeorge syndrome candidate gene, is required for cardiac outflow tract septation. Circ Res 84:127-135

82. Puech A, Saint-Jore B, Funke B, Gilbert DJ, Sirotkin H, Copeland NG, Jenkins NA Kucherlapati R, Morrow B, Skoultchi AI 1997 Comparative mapping of the human $22 \mathrm{q} 11$ chromosomal region and the orthologous region in mice reveals complex changes in gene organization. Proc Natl Acad Sci USA 94:14608-14613

83. Lund J, Roe B, Chen F, Budarf M, Galili N, Riblet R, Miller RD, Emanuel BS Reeves RH 1999 Sequence-ready physical map of the mouse chromosome 16 region with conserved synteny to the human velocardiofacial syndrome region on $22 \mathrm{q} 11.2$. Mamm Genome 10:438-443

84. Botta A, Lindsay EA, Jurecic V, Baldini A 1997 Comparative mapping of the DiGeorge syndrome region in mouse shows inconsistent gene order and differential degree of gene conservation. Mamm Genome 8:890-895

85. Galili N, Baldwin HS, Lund J, Reeves R, Gong W, Wang Z, Roe BA, Emanuel BS, Nayak S, Mickanin C, Budarf ML, Buck CA 1997 A region of mouse chromosome 16 is syntenic to the DiGeorge, velocardiofacial syndrome minimal critical region. Genome Res 7:17-26

86. Kimber WL, Hsieh P, Hirotsune S, Yuva-Paylor L, Sutherland HF, Chen A Ruiz-Lozano P, Hoogstraten-Miller SL, Chien KR, Paylor R, Scambler PJ, Wynshaw-Boris A 1999 Deletion of $150 \mathrm{~kb}$ in the minimal DiGeorge/velocardiofacia syndrome critical region in mouse. Hum Mol Genet 8:2229-2237

87. McQuade L, Christodoulou J, Budarf M, Sachdev R, Wilson M, Emanuel B, Colley A 1999 Patient with a 22q11.2 deletion with no overlap of the minimal DiGeorge syndrome critical region (MDGCR). Am J Med Genet 86:27-33

88. Rizzu P, Lindsay EA, Taylor C, O’Donnell H, Levy A, Scambler P, Baldini A 1996 Cloning and comparative mapping of a gene from the commonly deleted region of DiGeorge and Velocardiofacial syndromes conserved in C. elegans. Mamm Genome 7:639-643

89. Gottlieb S, Emanuel BS, Driscoll DA, Sellinger B, Wang Z, Roe B, Budarf ML 201 1997 The DiGeorge syndrome minimal critical region contains a goosecoid-like (GSCL) homeobox gene that is expressed early in human development. Am J Hum Genet 60:1194-1201

90. Heisterkamp N, Mulder MP, Langeveld A, ten Hoeve J, Wang Z, Roe BA, Groffen J 1995 Localization of the human mitochondrial citrate transporter protein gene to chromosome 22Q11 in the DiGeorge syndrome critical region. Genomics 29:451456

91. Goldmuntz E, Wang Z, Roe BA, Budarf ML 1996 Cloning, genomic organization, and chromosomal localization of human citrate transport protein to the DiGeorge/ velocardiofacial syndrome minimal critical region. Genomics 33:271-276

92. Holmes SE, Riazi MA, Gong W, McDermid HE, Sellinger BT, Hua A, Chen F, Wang Z, Zhang G, Roe B, Gonzalez I, McDonald-McGinn DM, Zackai E, Emanue BS, Budarf ML 1997 Disruption of the clathrin heavy chain-like gene (CLTCL) associated with features of DGS/VCFS: a balanced $(21 ; 22)(\mathrm{p} 12 ; \mathrm{q} 11)$ translocation. Hum Mol Genet 6:357-367
93. Sirotkin H, Morrow B, DasGupta R, Goldberg R, Patanjali SR, Shi G, Cannizzaro L, Shprintzen R, Weissman SM, Kucherlapati R 1996 Isolation of a new clathrin heavy chain gene with muscle-specific expression from the region commonly deleted in velo-cardio-facial syndrome. Hum Mol Genet 5:617-624

94. Pizzuti A, Novelli G, Mari A, Ratti A, Colosimo A, Amati F, Penso D, Sangiuolo F, Calabrese G, Palka G, Silani V, Gennarelli M, Mingarelli R, Scarlato G, Scambler P, Dallapiccola B 1996 Human homologue sequences to the Drosophila dishevelled segment- polarity gene are deleted in the DiGeorge syndrome. Am J Hum Genet 58:722-729

95. Pizzuti A, Novelli G, Ratti A, Amati F, Bordoni R, Mandich P, Bellone E, Conti E, Bengala M, Mari A, Silani V, Dallapiccola B 1999 Isolation and characterization of a novel transcript embedded within HIRA, a gene deleted in DiGeorge syndrome. Mol Genet Metab 67:227-235

96. Halford S, Wadey R, Roberts C, Daw SC, Whiting JA, O'Donnell H, Dunham I, Bentley D, Lindsay E, Baldini A, et al 1993 Isolation of a putative transcriptional regulator from the region of 22q11 deleted in DiGeorge syndrome, Shprintzen syndrome and familial congenital heart disease. Hum Mol Genet 2:2099-2107

97. Wilming LG, Snoeren CA, van Rijswijk A, Grosveld F, Meijers C 1997 The murine homologue of HIRA, a DiGeorge syndrome candidate gene, is expressed in embryonic structures affected in human CATCH22 patients. Hum Mol Genet 6:247-258

98. Pizzuti A, Novelli G, Ratti A, Amati F, Mari A, Calabrese G, Nicolis S, Silani V, Marino B, Scarlato G, Ottolenghi S, Dallapiccola B 1997 UFD1L, a developmentally expressed ubiquitination gene, is deleted in $\mathrm{CATCH} 22$ syndrome. Hum $\mathrm{Mol}$ Genet 6:259-265

99. Saha P, Thome KC, Yamaguchi R, Hou Z, Weremowicz S, Dutta A 2091998 The human homolog of Saccharomyces cerevisiae CDC45. J Biol Chem 273:1820518209

100. Sirotkin H, Morrow B, Saint-Jore B, Puech A, Das Gupta R, Patanjali SR, Skoultchi A, Weissman SM, Kucherlapati R 1997 Identification, characterization, and precise mapping of a human gene encoding a novel membrane-spanning protein from the $22 \mathrm{q} 11$ region deleted in velo-cardio-facial syndrome. Genomics 42:245-251

101. Zieger B, Hashimoto Y, Ware J 1997 Alternative expression of platelet glycoprotein $\mathrm{Ib}$ (beta) mRNA from an adjacent 5 ' gene with an imperfect polyadenylation signal sequence. J Clin Invest 99:520-525

102. Budarf ML, Konkle BA, Ludlow LB, Michaud D, Li M, Yamashiro DJ, McDonaldMcGinn D, Zackai EH, Driscoll DA 1995 Identification of a patient with BernardSoulier syndrome and a deletion in the DiGeorge/velo-cardio-facial chromosomal region in 22q11.2. Hum Mol Genet 4:763-766

103. Chapman DL, Garvey N, Hancock S, Alexiou M, Agulnik SI, Gibson-Brown JJ, Cebra-Thomas J, Bollag RJ, Silver LM, Papaioannou VE 1996 Expression of the T-box family genes, Tbx1-Tbx5, during early mouse development. Dev Dyn 206:379-390

104. Halford S, Wilson DI, Daw SC, Roberts C, Wadey R, Kamath S, Wickremasinghe A, Burn J, Goodship J, Mattei MG, et al 1993 Isolation of a gene expressed during early embryogenesis from the region of 22q11 commonly deleted in DiGeorge syndrome. Hum Mol Genet 2:1577-1582

105. Brahe C, Bannetta P, Serra A, Arwert F 1986 The increased COMT activity in Down syndrome patients is not a consequence of dosage effect owing to location of the gene on chromosome 21: further evidence. Am J Med Genet 24:203-204

106. Sirotkin H, O’Donnell H, DasGupta R, Halford S, St. Jore B, Puech A, Parimoo S, Morrow B, Skoultchi A, Weissman SM, Scambler P, Kucherlapati R 1997 Identification of a new human catenin gene family member (ARVCF) from the region deleted in velo-cardio-facial syndrome. Genomics 41:75-83

107. Emanuel BS, Driscoll D, Goldmuntz E, Baldwin S, Biegel J, Zackai EH, McDonaldMcGinn D, Sellinger B, Gorman N, Williams S, et al 1993 Molecular and phenotypic analysis of the chromosome 22 microdeletion syndromes. Prog Clin Biol Res 384:207-224

108. Demczuk S, Thomas G, Aurias A 1996 Isolation of a novel gene from the DiGeorge syndrome critical region with homology to Drosophila gdl and to human LAMC1 genes. Hum Mol Genet 5:633-638

109. Kurahashi H, Akagi K, Inazawa J, Ohta T, Niikawa N, Kayatani F, Sano T, Okada S, Nishisho I 1995 Isolation and characterization of a novel gene deleted in DiGeorge syndrome. Hum Mol Genet 4:541-549

110. Aubry M, Demczuk S, Desmaze C, Aikem M, Aurias A, Julien JP, Rouleau GA 1993 Isolation of a zinc finger gene consistently deleted in DiGeorge syndrome. Hum Mol Genet 2:1583-1587

111. Netter FH 1991 Heart. In: Yonkman FF (ed) The CIBA Collection of Medical Illustrations. The Hennegan Co., Cincinnati, pp 118-129 